\title{
A ascensão, o fausto, a decadência, a importância e os riscos da Casa da Velha Senhora
}

Prezada Editora:

- Conta, vai !... Conta a história do Brasil!

- Eu não, eu não sou masoquista!

"Auto dos 99 por cento" - Peça teatral do Centro

Popular de Cultura da UNE - Anos 60

A Senhora, nascida nas terras de Santa Cruz, era de boa cepa. Descendia dos europeus que aqui aportaram e seus problemas disseminaram-se nos nativos entre quinquilharias lusitanas e palavras catequéticas dos doentios, mas dedicados jesuítas. Ainda que herança das caravelas, a Coroa nada fez para assistir os problemas a ela relacionados na colônia do pau-brasil.

No seguinte Império, um flagelo mortal bem documentado na capital do Rio de J aneiro, os amigos da Senhora continuavam quase sem nenhuma assistência. 0 quase coube à piedade e à misericórdia das casas santas, uma tradição que acompanhava os portugueses em suas naveganças mar afora.

Nesses tempos, justificando o desinteresse, os amigos da Senhora incluíam predominantemente nativos locais, escravos trazidos da África e outros setores carentes da sociedade.

As notícias da Europa e os avanços dos conhecimentos influenciaram timidamente a República emergente. A té 1930, as iniciativas da sociedade foram bem mais presentes que as do setor público. Multiplicavam-se as ligas e as sociedades organizadas, embrião dos sindicatos e das atuais decantadas ONGs.

Como uma cortesã, a Senhora conquistava, em suas alcovas, figuras prestigiosas da medicina e da intelectualidade republicana: os paulistas Clemente Ferreira, Emílio Ribas e Guilherme Álvaro; os cariocas H ilário Gouveia, Cypriano de Freitas, Paranhos Pederneira, Clementino Fraga, Antonio Cardoso Fontes; os pernambucanos Octávio de Freitas e Flácido Barbosa e os baianos Ramiro de Azevedo, César de A raújo e J osé Silveira.

0 terreno era inóspito, mas as necessidades frente à amplitude que assumia aquela Senhora levaram o Estado a iniciar a construção de sua Casa. Sua amplitude, é verdade, além dos párias e produtores, alcançava alguns setores influentes, particularmente a intelectualidade, provocando um

Endereço para correspondência - Rua A bílio Soares, 233, Paraíso 04055-000 - São Paulo, SP. Tel./fax: (11) 885-7827; E-mail: fiuza@mandic.com.br mal-estar já experimentado por europeus e americanos do Norte.

Comentava-se, discretamente, que a Noite era responsável, pois nela, como nos Cemitérios, igualam-se os pobres e os ricos, nestes porque todos retornam ao barro, naquela, pela busca de prazeres e migalhas, onde a boêmia e a escuridão facilitavam a disseminação da influência da tal Senhora.

Desenvolvem-se, em 1941, as primeiras iniciativas ministeriais com a criação de um serviço voltado para construir uma Casa que albergasse a Senhora e seus amigos. 0 prédio era sólido em sua origem e, sem dúvida, contribuiu enormemente para impedir que o motivo de seu aparecimento se exacerbasse.

0 aporte de verbas, pela pressão social e a dimensão do problema, permitiu um requinte raramente experimentado por construções similares. Seu estilo era barroco, competindo uma mistura de "nacional-modernismo" europeu e "realismo-tupiniquim" em seus adornos.

$N$ as estantes de sua biblioteca era fácil identificar, entre outras, obras de Kafka, Goethe, R ousseau, Robert Louis Stevenson, as Bronté (Charlotte, Emily e Anne), Thomas Mann, além dos poemas de Lamartine, Sir Walter Scott e Shelley e as peças de Molière e Anton Chekhov. Na seção nacional, Castro Alves, A ugusto dos A njos, Casimiro de A breu, Emílio de Menezes, até Dinah Silveira e Manuel Bandeira, entre tantos mais. O bras de pintores famosos, como J ean-Antoine Watteau, Elizabeth Siddal e Modigliani disputavam as paredes com gravuras e fotos de famosas personagens, desde Cícero, Richelieu a Eleanor Roosevelt e Nelson Mandela, sem esquecer Marguerite Gautier, a "Dama das Camélias", na verdade Maria Duplessis, uma prostituta de bons sentimentos, conhecida e imortalizada por Dumas Filho e a hollywoodiana Vivien Leigh. Tudo isso, acompanhados por um fundo musical clássico inebriante de Pergolesi e Paganini, o som predominantemente marcial de Chopin e óperas de Bizet. Para os mais ligados ao popular nacional, os prazerosos sambas de N oel Rosa ou as engajadas melodias de Gonzaguinha.

A Casa da Senhora, poderosa e imponente, dominou, por quase três décadas, a paisagem pública, com inegáveis contribuições e conquistas.

O tempo passou... Mudou a realidade... E a Senhora envelheceu...

Confiante de que suas recomendações, por si sós, seriam o suficiente para equacionar os problemas, preocupava-se 
com o genérico e esquecia o trivial da aplicação de suas propostas.

Outra vez, entre os usuários da Casa da (agora) Velha Senhora, predominavam os humildes e subnutridos. E, com eles, o esquecimento social e a decadência. As velhas ligas e sociedades feneceram ou perderam a pujança do passado. A importância do passado, entretanto, era tanta, que ávidos mantenedores ainda disputavam suas alcovas e mezaninos, crentes no prestígio e nas benesses de um poder que se esvaiu.

Com recursos minguados e por não adaptar-se aos novos tempos, descuidaram de sua manutenção. Os jardins cobriram-se de mato, a pintura perdeu o vigor, tornaram-se sombrias suas dependências. 0 lixo era varrido para debaixo dos tapetes, os resíduos sem solução entupiam os esgotos, abalando as estruturas. Com o abandono, a Casa da Velha Senhora apresentava sérios riscos de desabamento, maculando com um odor mofo e pútrido a paisagem liberal-desenvolvimentista instalada nos arredores.

Por sorte ou conseqüência de desgraça semelhante, na área da Casa da Velha Senhora apareceram novas construções, uma delas bem a seu lado.

Era a Mansão do J ovem Negro, um nouveau riche, de origem intrigante e ecológica dos rincões africanos. Este migrante poderoso insinuou-se rapidamente nas metrópoles, favorecido pela liberação sexual e busca de prazeres venosos, ganhando manchetes e importância. A pressão social também se fez presente, não por ligas e sociedades piedosas mas, agora, por ativas e intrépidas ONGs.

Com isso, fartura de recursos, modelando a Mansão tal como um "arranha-céu" do Norte continental e logo freqüentada por universalistas atentos e produtores miméticos, sequiosos pela oportunidade em auferir denodo e investimentos.

Aos amigos e visitantes do novo prédio, chamava a atenção aquela velha Casa vizinha, cujos limites acabavam por se confundir com os da Mansão.

\section{REFERÊNCIAS}

1. Ribeiro L. A luta contra a tuberculose no Brasil. Apontamentos para sua história. Rio de J aneiro, 1956.

2. Reibaum J. Phthisis and the arts. In: Ron WN, Garay S, eds. Tuberculosis. New York: Little, Brown and Co., 1996.

3. Fiuza de Melo FA. Problemas atuais da tuberculose: correlação com a Aids, multirresistência, riscos ocupacionais e outros. Entrevista. Âmbito Hospitalar 1993;8.
Com parentes emergentes acima do equador, a Velha Senhora, aqui permanecente e estigmatizada, continuava com ampla influência social, olvidada pela falsa certeza de problema solucionado e principalmente pela desimportância de seus usuários.

De sobra, a convivência com o J ovem do lado, quem diria, permitiu à Velha Senhora conquistar novamente amigos importantes. U ma supervisão seguida de dote providenciou uma reforma na Casa, na tentativa de recuperar o fausto dos tempos idos.

Seja por negligência ou pelo modo afoito com que se fez a reforma, o lixo e os resíduos foram esquecidos. Desavisados que nela adentrem podem cair ao tropeçar na elevação do tapete. Permanece o risco de ela ruir na cabeça de reformadores precipitados.

A Casa da Velha Senhora, ainda que esquecida, mantémse profundamente arraigada na população, exigindo respeito e atenção que esta realidade lhe confere.

U ma reforma responsável pode gerar lucros e benefícios, tanto para humildes visitantes, amigos constantes, abnegados colaboradores e mesmo para ávidos mantenedores.

Há, entretanto, que não esquecer do seu lixo crônico e seus resíduos multirresistentes. 0 risco será torná-los rotineiros...

Qualquer semel hança com a tubercul ose e o HIV é mera coincidência.

Inspirado em pacientes portadores de TB multirresistente que reativaram sua doença, após meses de escarro negativo, por falta de medicação para continuidade do tratamento alternativo.

FERnando Augusto Fiuza de Melo

Médico do Instituto Clemente Ferreira e do Serviço de Doenças Respiratórias do HSPE-SP - São Paulo

4. Fiuza de Melo FA. Tuberculose e Aids. Relações e coincidências. Cadernos pela Vida 1993;10.

5. Rosemberg J. Tuberculosos notáveis. Pneumologia Paulista 1993;6.

6. Silveira J. U ma doença esquecida. A história da tuberculose na Bahia. Salvador: Centro Editorial e Didático, 1996. 